\title{
Peran Diskusi Suami Istri terhadap Kepatuhan Kunjungan Antenatal Care (ANC)
}

\author{
Fadhila Tri Cahyanti, Supriyadi, Ema Novita Deniati* \\ Universitas Negeri Malang, Jl. Semarang No. 5 Malang, Jawa Timur, Indonesia \\ *Penulis korespondensi, Surel: ema.deniati.fik@um.ac.id
}

Paper received: 1-10-2021; revised: 19-10-2021; accepted: 25-10-2021

\begin{abstract}
Every marriage must experience various problems that occur especially in the wrong communication between husband and wife. A true communication must be well established, especially during the wife's pregnancy, especially for the husband. The East Java Provincial Health Office stated that the K4 coverage for East Java Province was 91.15 percent. Pamekasan Regency is a Regency in East Java that has less desire for visits to pregnant women's health services is 92,75 percent, while target MSS. This study uses an observational quantitative cross-sectional approach with a sample of 112 married couples determined using the technique Accidental Sampling. Data collection using questionnaires includes two parts, namely husband's discussion and wife's discussion, based on The results show that there is an influence between husband's discussion on ANC visits and there is no influence between wife's discussion on ANC visits with the meaning that there is a role for husband and wife discussions to encourage ANC visits. the health of the wife and fetus is healthy until the delivery is smooth. And improve and develop programs related to the promotion of maternal and child health (MCH).
\end{abstract}

Keywords: husband and wife discussion; ANC

\begin{abstract}
Abstrak
Setiap pernikahan pasti mengalami berbagai masalah yang terjadi terutama pada komunikasi yang salah antara suami istri. Suatu komunikasi sejatinya harus terjalin dengan baik terutama pada masa kehamilan istri, terutama bagi suami. Dinas Kesehatan Provinsi Jawa Timur menyatakan bahwa cakupan K4 untuk Provinsi Jawa Timur sebesar 91,15. Kabupaten Pamekasan merupakan Kabupaten di Jawa Timur yang mempunyai hasrat kunjungan yang kurang terhadap pelayanan kesehatan ibu hamil adalah 92,75 persen, sedangkan sasaran SPM Penelitian ini menggunakan kuantitatif observasional pendekatan Cross Sectional dengan jumlah sampel 112 pasangan suami istri yang ditentukan dengan menggunakan teknik Accidental Sampling. Pengumpulan data menggunakan penyebaran kuesioner meliputi dua bagian yaitu diskusi suami dan diskus istri, berdasarkan hasil bahwa ada pengaruh antara diskusi suami terhadap kunjungan ANC dan tidak ada pengaruh antara diskusi istri terhadap kunjungan ANC dengan makna ada peran diskusi suami dan istri terhadap mendorong melakukan kunjungan ANC. Dan diharapkan dapat meningkatkan komunikasi dan motivasi kepada sang istri terhadap kepatuhan kunjungan ANC agar kesehatan istri dan janin sehat hingga persalinannya pun lancar. Dan meningkatkan dan mengembangkan program-program terkait promosi kesehatan Ibu dan Anak (KIA).
\end{abstract}

Kata kunci: diskusi suami istri; ANC

\section{Pendahuluan}

Setiap pernikahan pasti mengalami berbagai masalah yang terjadi terutama pada komunikasi yang salah antara suami istri. Suatu komunikasi sejatinya harus terjalin dengan baik terutama pada masa kehamilan istri, terutama bagi suami. Suami tidak hanya berperan sebagai pendamping hidup dan pencari nafkah, lebih dari itu suami juga berperan sebagai motivator dalam suatu keputusan atau kebijakan yang berkaitan dengan perencanaan keluarga (Chaniago dalam Nursalam, 2007). Terdapatnya support serta perilaku positif dari 
suami hendak menciptakan proses kehamilan berjalan menyenangkan serta pastinya menjadikan keadaan yang sehat untuk kandungan (Nurdiansyah dalam Sari, 2015). Masa kehamilan memiliki tahapan dan proses yang cukup panjang dan cukup rentan bagi calon ibu. Adapun yang harus menjadi perhatian bagi adalah kondisi istri yang sedang hamil, baik itu kesehatannya, perawatannya hingga mengenai hubungan intim. Setiap ibu hamil pastinya menginginkan kelancaran pada proses kehamilan hingga dengan persalinan, sehingga tidak terjadinya komplikasi pada kehamilan serta persalinan, setiap ibu mengandung disarankan buat melaksanakan pengecekan kehamilan secara berkala.

Data dari World Health Organization (WHO) menyatakan jika di segala dunia, tiap harinya ditemukan permasalahan sebanyak 830 perempuan yang meninggal diakibatkan karena terbentuknya komplikasi kehamilan serta persalinan, sedangkan secara totalitas, angka AKI sebanyak 303. 000/ 100. 000 kelahiran hidup. Ada pula di Tahun 2018, tiap harinya ada 38 ibu yang meninggal dunia akibat komplikasi terkait kehamilan serta persalinan (Key Fact WHO, 2018). Provinsi Jawa Timur termasuk dalam provinsi lainnya dengan angka kematian ibu serta bayi melahirkan yang cukup teratas di Indonesia. Tercatat di Tahun 2018 ada sebanyak 431 ibu serta anak yang meninggal pada saat melahirkan (Fitria Dewi dalam Nasrullah, 2018).

Dinas Kesehatan Provinsi Jawa Timur menyebutkan bahwa AKI di Jawa Timur mencapai 91,45\% setiap 1000 kelahiran pada Tahun 2018. Penyebab tingginya AKI disebabkan oleh beberapa faktor yaitu 32,57\%, preeklampsia dan eklampsia 31,32 \%, perdarahan 22,8\%, dan infeksi 3,64\%. (Kemkes, 2018). Dinas Kesehatan Provinsi Jawa Timur menyatakan bahwa cakupan K4 untuk Provinsi Jawa Timur sebesar 91,15\% (Dinkes Provinsi Jawa Timur, 2018). Kabupaten Pamekasan salah satu Kabupaten di Jawa Timur yang memiliki minat kunjungan yang kurang terhadap pelayanan kesehatan ibu hamil yaitu 92,75\%, sedangkan target SPM (Standar Pelayanan Minimal) ialah 100\%, (Dinkes Provinsi Jawa Timur, 2018).

Dinas Kesehatan Provinsi Jawa Timur menyatakan bahwa cakupan K4 untuk Provinsi Jawa Timur sebesar 91,15\% (Dinkes Provinsi Jawa Timur, 2018). Berdasarkan data, Angka Kematian Ibu dan Bayi atau AKI dan AKB di Jawa Timur mencapai 90/10.000 kelahiran yang menjadikannya sebagai provinsi yang belum mencapai target SDGs yang ditetapkan 70/10.000 kelahiran. (Ermalena, 2017). Kabupaten Pamekasan merupakan Kabupaten di Jawa Timur yang mempunyai hasrat kunjungan yang kurang terhadap pelayanan kesehatan ibu hamil adalah 92, 75\%, sedangkan sasaran SPM (Standar Pelayanan Minimal) merupakan 100\% (Dinkes Provinsi Jawa Timur, 2018). Data tahun 2017 menunjukkan bahwa pada kabupaten Pamekasan, angka AKI berjumlah 8 kasus dan AKB sebanyak 52 kasus (Basri, 2019). Data yang menunjukan dalam penelitian ini yang dilaksanakan pada wilayah kerja Puskesmas Waru Kabupaten Pamekasan bahwa kesadaran situasi ibu hamil berada pada tingkat 2 adalah tingkatan pemahaman seorang ibu hamil terhadap situasi yang dialami. Namun, masih banyak ditemukan tingkatan pemahaman pada tingkat 1 atau belum sampai pada tingkat pemahaman. (Sendy dkk, 2017). Pelaksanaan pelayanan kesehatan berupa Antenatal Care (ANC) pada ibu hamil sudah rutin dilakukan, namun kesadaran ibu hamil cukup kurang dengan pelaksanaan pemeriksaan kehamilan.

ANC merupakan pemeriksaan kehamilan yang sangat penting dilakukan saat yang akan memasuki masa kehamilan. Pengetahuan terhadap ANC mampu mengurangi Angka Kematian Ibu (AKI) dan Angka Kematian Bayi (AKB). Kepatuhan ANC dapat dipengaruhi oleh dukungan 
keluarga terutama suami. Beberapa hasil penelitian menunjukkan bahwa banyak dari ibu hamil yang akan melaksanakan kunjungan ANC tanpa didampingi oleh pihak suami atau keluarga yang lain (Sari dan Eny, 2015). Dan hal yang sama bahwa penelitian yang dilakukan oleh Pakki (2018), bahwa dukungan suami memiliki hubungan yang positif terhadap kepatuhan $A N C$ ibu hamil.

Berdasarkan penjelasan diatas diketahui bahwa dukungan suami terhadap kepatuhan kunjungan ANC masih tergolong rendah. Oleh karena itu, untuk mendapatkan informasi lebih dalam terutama pada kunjungan ibu hamil di rumah sakit, maka dibutuhkan suatu riset mengenai "Peran Diskusi Suami Istri terhadap Kepatuhan Kunjungan ANC RSUD Dr. H. Slamet Martodirdjo Pamekasan”.

\section{Metode}

Peneliti ini akan menggunakan rancangan kuantitatif observasional dengan pendekatan Cross Sectional. Penelitian ini dilaksanakan dalam kurun waktu dua bulan yaitu pada 23 januari- 23 maret 2021. Populasi yang digunakan berjumlah 112 pasangan suami istri yang ditentukan dengan teknik Accidental Sampling. Dalam pengambilan sampel terdapat kriteria inklusi dan eksklusi. Kriteria inklusi dalam penelitian ini yaitu 1. Tinggal di wilayah RSUD Dr. H. Slamet Martodirdjo Pamekasan minimal enam bulan (bagi suami dan istri) 2. Tercatat dan pernah memeriksakan kehamilan di RSUD Dr. H. Slamet Martodirdjo Pamekasan minimal enam bulan (bagi istri) 3. Bersedia menjadi responden penelitian (bagi suami dan istri) 4 . Memiliki buku KIA (bagi istri) 5. Responden yang sehat jasmani dan rohani (bagi suami dan istri). Penelitian ini memiliki kriteria eksklusi yaitu 1 . Suami atau istri mengundurkan diri dari responden 2. Ibu hamil apabila saat melakukan pengisian kuesioner tidak melanjutkan pengisian karena sesuatu hal seperti sakit dan lain sebagainya. Menggunakan kuesioner diskusi suami dan diskusi istri ini telah dimodifikasi oleh peneliti dan dilakukan uji validitas dengan hasil perhitungan nilai $\mathrm{r}=1$ dan telah diuji reliabilitas dengan nilai Cronbach Alpha sebesar 0,960 yang artinya kuesioner ini telah valid dan reliabel untuk digunakan di lapangan.

\section{Hasil dan Pembahasan}

\subsection{Karakteristik Responden}

\subsubsection{Responden Berdasarkan Usia Suami}

Tabel 1. Karakteristik Responden Berdasarkan Usia Suami

\begin{tabular}{ccc}
\hline Usia & Jumlah & Persentase \\
\hline $15-25$ & 33 & $29 \%$ \\
$26-35$ & 57 & $51 \%$ \\
$36-45$ & 20 & $18 \%$ \\
$46-55$ & 2 & $2 \%$ \\
\hline Total & 112 & $100 \%$ \\
\hline
\end{tabular}

Berdasarkan tabel 1 didapatkan hasil bahwa kategori usia pada suami 15-25 tahun yaitu sebanyak $29 \%$ atau 33 suami, usia 26-35 tahun yaitu sebanyak $51 \%$ atau 57 suami, usia 36-45 tahun yaitu sebanyak $18 \%$ atau 20 suami, usia 46-55 yaitu sebanyak $2 \%$ atau 2 suami. Berdasarkan hasil distribusi frekuensi tersebut diperoleh bahwa mayoritas usia suami berada dalam rentang 26-35 tahun sebesar $51 \%$ atau sebanyak 57 suami yang menunjukkan juga 
bahwa suami berada pada titik emosi yang stabil menurut usianya dan masih masuk dalam usia produktif seseorang.

\subsubsection{Responden Berdasarkan Usia Istri}

Tabel 2. Karakteristik Responden Berdasarkan Usia Istri

\begin{tabular}{ccc}
\hline Usia & Jumlah & Persentase \\
\hline $15-25$ & 58 & $52 \%$ \\
$26-35$ & 47 & $42 \%$ \\
$36-45$ & 7 & $6 \%$ \\
$46-55$ & 0 & $0 \%$ \\
\hline Total & 112 & $100 \%$ \\
\hline
\end{tabular}

Berdasarkan hasil tabel 2 menyatakan bahwa kategori usia pada istri 15-25 tahun yaitu sebanyak $58 \%$ atau 58 istri, usia 26-35 tahun yaitu $42 \%$ atau 47 istri, usia 36-45 tahun yaitu sebanyak $6 \%$ atau 7 istri, dan tidak ada responden yang berusia antara rentang 46-55 tahun. Berdasarkan hasil distribusi frekuensi diketahui bahwa mayoritas usia istri berada dalam rentang 15-25 tahun yaitu sebanyak 58\% atau 58 istri. Distribusi ini menunjukkan bahwa kematangan istri pada dalam fase post-pubertas dan atau dewasa awal, sehingga tingkat kematangan emosional wanita cenderung mengalami ketidakstabilan.

\subsubsection{Responden Berdasarkan Pendidikan Suami}

Tabel 2. Karakteristik Responden Berdasarkan Pendidikan Suami

\begin{tabular}{lcc}
\hline Pendidikan & Jumlah & Persentase \\
\hline Tidak sekolah/Tidak tamat SD & 0 & $0 \%$ \\
Tamat SD & 3 & $3 \%$ \\
Tamat SLTP/Sederajat & 10 & $9 \%$ \\
Tamat SLTA/Sederajat & 57 & $51 \%$ \\
Akademi/Perguruan Tinggi & 42 & $38 \%$ \\
\hline Total & 112 & $100 \%$ \\
\hline
\end{tabular}

Berdasarkan hasil tabel 3 menyatakan bahwa kategori pendidikan suami tamat SD yaitu 3\% atau 3 suami, pendidikan Tamat SLTP/Sederajat yaitu 9\% atau 10 suami, pendidikan Tamat SLTA/Sederajat yaitu $51 \%$ atau 57 suami, dan pendidikan Akademi/Perguruan Tinggi yaitu 38\% atau 42 suami. Berdasarkan hasil distribusi frekuensi diketahui bahwa mayoritas pendidikan paling banyak adalah Tamat SLTA/Sederajat yaitu 51\% atau 57 suam. Hal tersebut terjadi dikarenakan mayoritas penduduk setelah lulus dari SLTA/Sederajat lebih memilih untuk bekerja sebagai wiraswasta. 


\subsubsection{Responden Berdasarkan Pendidikan Istri}

Tabel 4. Karakteristik Responden Berdasarkan Pendidikan Istri

\begin{tabular}{lcc}
\hline \multicolumn{1}{c}{ Pendidikan } & Jumlah & Persentase \\
\hline Tidak sekolah/Tidak tamat SD & 0 & $0 \%$ \\
Tamat SD & 9 & $8 \%$ \\
Tamat SLTP/Sederajat & 15 & $13 \%$ \\
Tamat SLTA/Sederajat & 44 & $39 \%$ \\
Akademi/Perguruan Tinggi & 44 & $39 \%$ \\
\hline Total & 112 & $100 \%$ \\
\hline
\end{tabular}

Berdasarkan hasil tabel 4 menyatakan bahwa kategori pendidikan istri Tamat SD yaitu sebanyak $8 \%$ atau 9 istri, pendidikan Tamat SLTP/Sederajat yaitu sebanyak $13 \%$ atau 15 istri, pendidikan Tamat SLTA/Sederajat yaitu sebanyak 39\% atau 44 istri dan pendidikan Akademi/Perguruan Tinggi yaitu sebanyak 44 istri.

\subsubsection{Responden Berdasarkan Pekerjaan Suami}

Tabel 3. Karakteristik Responden Berdasarkan Pekerjaan Suami

\begin{tabular}{lcc}
\hline Pekerjaan & Jumlah & Persentase \\
\hline Ibu Rumah Tangga & 0 & $0 \%$ \\
Buruh & 3 & $3 \%$ \\
Pengusaha & 0 & $0 \%$ \\
PNS & 4 & $4 \%$ \\
Wiraswasta & 78 & $70 \%$ \\
Lain-lainya & 27 & $24 \%$ \\
Total & 112 & \\
\hline
\end{tabular}

Berdasarkan hasil tabel 5 menyatakan bahwa kategori pekerjaan suami buruh yaitu sebanyak 3\% atau 3 suami, pekerjaan PNS yaitu sebanyak $4 \%$ atau 4 suami, pekerjaan wiraswasta yaitu sebanyak $70 \%$ atau 78 suami, pekerjaan lain-lainnya yaitu sebanyak $24 \%$ atau 27 suami.

\subsubsection{Responden Berdasarkan Pekerjaan Istri}

Tabel 4. Karakteristik Responden Berdasarkan Pekerjaan Istri

\begin{tabular}{lcc}
\hline Pekerjaan & Jumlah & Persentase \\
\hline Ibu Rumah Tangga & 86 & $77 \%$ \\
Buruh & 0 & $0 \%$ \\
Pengusaha & 0 & $0 \%$ \\
PNS & 5 & $4 \%$ \\
Wiraswasta & 11 & $10 \%$ \\
Lain-Lainya & 10 & $9 \%$ \\
\hline Total & 112 & $100 \%$ \\
\hline
\end{tabular}

Berdasarkan hasil tabel 6 menyatakan bahwa kategori pekerjaan istri ibu rumah tangga yaitu sebanyak $77 \%$ atau 86 istri, pekerjaan PNS yaitu sebanyak $4 \%$ atau 5 istri, pekerjaan wiraswasta yaitu sebanyak $10 \%$ atau 11 istri, pekerjaan lain-lainya yaitu sebanyak $9 \%$ atau 10 
istri. Berdasarkan hasil distribusi frekuensi diketahui bahwa mayoritas pekerjaan paling banyak adalah ibu rumah tangga yang berjumlah $77 \%$ atau 86 istri. Hal tersebut terjadi karena istri memilih untuk tidak melanjutkan ke jenjang selanjutnya (Akademi/Perguruan Tinggi) dan menjadi ibu rumah tangga.

\subsection{Hasil Analisis Univariat}

\subsubsection{Distribusi Frekuensi Berdasarkan Diskusi Suami}

Tabel 7. Distribusi Frekuensi Berdasarkan Diskusi Suami

\begin{tabular}{lcc}
\hline Diskusi suami & Jumlah & Persentase \\
\hline Rendah & 68 & $61 \%$ \\
Tinggi & 44 & $39 \%$ \\
\hline Total & 112 & $100 \%$ \\
\hline
\end{tabular}

Berdasarkan hasil tabel 7 menyatakan bahwa diskusi Suami masih tergolong rendah yaitu sebesar $61 \%$ atau 68 suami, sedangkan diskusi suami yang tergolong tinggi yaitu sebesar $39 \%$ atau 44 suami dan keseluruhan responden berjumlah 112 suami.

\subsubsection{Distribusi Frekuensi Berdasarkan Diskusi Istri}

Tabel 8. Distribusi Frekuensi Berdasarkan Diskusi Istri

\begin{tabular}{lcc}
\hline Diskusi Istri & Jumlah & Persentase \\
\hline Rendah & 44 & $39 \%$ \\
Tinggi & 68 & $61 \%$ \\
\hline Total & 112 & $100 \%$ \\
\hline
\end{tabular}

Berdasarkan hasil tabel 8 menyatakan bahwa diskusi istri yang tergolong rendah yaitu sebesar 39\% atau 44 istri. Sedangkan diskusi istri yang tergolong tinggi yaitu sebanyak 61\% atau 68 istri. Dan keseluruhan jumlah responden yaitu 112 istri.

\subsubsection{Distribusi Frekuensi Berdasarkan Kunjungan ANC}

Tabel 9. Distribusi Frekuensi Berdasarkan Kunjungan ANC

\begin{tabular}{lcc}
\hline Kunjungan ANC & Jumlah & Persentase \\
\hline Sesuai & 53 & $47 \%$ \\
Tidak Sesuai & 59 & $53 \%$ \\
\hline Total & 112 & $100 \%$ \\
\hline
\end{tabular}

Berdasarkan hasil tabel 9 menyatakan bahwa kunjungan ANC di RSUD Dr. H. Slamet Martodirdjo terhadap diskusi suami istri yang sesuai yaitu sebanyak $47 \%$ atau 53 responden. Sedangkan kunjungan ANC di RSUD Dr. H. Slamet Martodirdjo terhadap diskusi suami istri yang tidak sesuai yaitu sebanyak $53 \%$ atau 59 responden dan keseluruhan responden berjumlah 112 pasangan suami istri. 


\subsection{Hasil Analisis Bivariat}

\subsubsection{Pengaruh Diskusi Suami Terhadap Kunjungan ANC}

Tabel 10. Hasil Analisis Pengaruh Diskusi Suami Terhadap Kunjungan ANC

\begin{tabular}{|c|c|c|c|c|c|c|c|}
\hline \multirow{3}{*}{ Variabel } & \multicolumn{4}{|c|}{ Kunjungan ANC } & \multirow{2}{*}{\multicolumn{2}{|c|}{ Jumlah }} & \multirow{3}{*}{ P-Value } \\
\hline & \multicolumn{2}{|c|}{ Tidak Sesuai } & \multicolumn{2}{|c|}{ Sesuai } & & & \\
\hline & $\mathbf{N}$ & $\%$ & $\mathbf{N}$ & $\%$ & $\mathbf{N}$ & $\%$ & \\
\hline Diskusi Suami & & & & & & & \\
\hline Rendah & 40 & 35,7 & 28 & 25 & 68 & 60,7 & 0,002 \\
\hline Tinggi & 13 & 11,6 & 31 & 27,7 & 44 & 39,3 & \\
\hline Jumlah & 53 & 47,3 & 59 & 52,7 & 112 & 100 & \\
\hline
\end{tabular}

Berdasarkan hasil tabel 10 diskusi suami terhadap kunjungan ANC didapatkan hasil uji statistik Chi Square menunjukan nilai p value=0,002 dan nilai Chi Square hitung $=9,186$ sedangkan nilai Chi Square tabel dengan $\mathrm{df}=1$ diperoleh nilai sebesar 3,841. Nilai Chi Square hitung $(9,186)$ lebih besar daripada nilai Chi Square tabel $(3,841)$ atau nilai p value $(0,002)$ lebih kecil daripada alpha $(0,05)$ maka menunjukkan hasil bahwa ada pengaruh antara diskusi suami dengan kunjungan ANC.

\subsubsection{Pengaruh Diskusi Istri Terhadap Kunjungan ANC}

Tabel 11. Hasil Analisis Pengaruh Diskusi Istri Terhadap Kunjungan ANC

\begin{tabular}{|c|c|c|c|c|c|c|c|}
\hline \multirow[t]{3}{*}{ Variabel } & \multicolumn{4}{|c|}{ Kunjungan ANC } & \multicolumn{2}{|c|}{ Jumlah } & \multirow[t]{3}{*}{ P-Value } \\
\hline & \multicolumn{2}{|c|}{ Tidak Sesuai } & \multicolumn{2}{|c|}{ Sesuai } & \multirow[b]{2}{*}{$\mathbf{N}$} & & \\
\hline & $\mathbf{N}$ & $\%$ & $\mathbf{N}$ & $\%$ & & & \\
\hline Diskusi Istri & & & & & & & \\
\hline Rendah & 19 & 17 & 25 & 22,3 & 44 & 39,3 & \\
\hline Tinggi & 34 & 30,3 & 34 & 30,4 & 68 & 60,7 & 0,480 \\
\hline Jumlah & 53 & 47,3 & 59 & 52,7 & 112 & 100 & \\
\hline
\end{tabular}

Berdasarkan hasil tabel 11 diskusi istri terhadap kunjungan ANC didapatkan hasil uji statistik Chi Square menunjukan nilai p value $=0,480$ dan nilai Chi Square hitung $=0,498$ sedangkan nilai Chi Square tabel dengan $\mathrm{df}=1$ diperoleh nilai sebesar 3,841. Nilai Chi Square hitung $(0,498)$ lebih kecil daripada nilai Chi Square tabel $(3,841)$ atau nilai p value $(0,480)$ lebih besar daripada alpha $(0,05)$ maka menunjukkan bahwa tidak ada pengaruh antara diskusi istri dengan kunjungan ANC.

\subsection{Hasil Analisis Multivariat}

\subsubsection{Menilai Keseluruhan Model Regresi}

Tabel 5. Hasil Uji Hosmer And Lemeshow Test

\begin{tabular}{cccc}
\hline Step & Chi- square & df & Sig. \\
\hline 1 & 2.740 & 2 & 0,254 \\
\hline
\end{tabular}


Berdasarkan hasil tabel 12 pengujian kesamaan model prediksi dengan observasi didapatkan nilai chi square sebesar 2,740 dengan signifikansi sebesar 0,254. Sedangkan nilai signifikansi yang lebih kecil dari 0,05 maka berarti adanya pengaruh antara data estimasi model regresi logistik dengan data observasinya. hal ini berarti model tersebut tepat atau tidak perlu adanya modifikasi model.

\subsubsection{Menilai Keseluruhan Model (Overall Model Fit)}

Tabel 6. Omnibus Test

\begin{tabular}{lllll}
\hline & & Chi- square & Df & Sig. \\
Step 1 & Step & 13,077 & 2 & 0,001 \\
& Block & 13,077 & 2 & 0,001 \\
& Model & 13,077 & 2 & 0,001 \\
\hline
\end{tabular}

Berdasarkan hasil tabel 13 omnibus test (Overall Model Fit) mendapatkan nilai chi square sebesar 13,077 dengan nilai signifikansi sebesar 0,001. Nilai $p=0,001<\alpha=0,05$ maka dapat disimpulkan penggunaan dua variabel bebas berpengaruh terhadap variabel terikat.

\subsubsection{Koefisien Determinasi (Nagelkerke R Square)}

Tabel 7. Hasil Uji Koefisien Determinasi

\begin{tabular}{llll}
\hline Step & -2log likelihood & Cox\&snell r square & Nagelkerke R square \\
\hline 1 & 141,866 & 0,110 & 0,147 \\
\hline
\end{tabular}

Berdasarkan tabel 14 nilai $\mathrm{G}$ adalah 141,866. Kemudian nilai $R$ square diukur dengan Nagelkerke R square sebesar 0,147. Maka berarti 14,7\% kunjungan ANC dapat dijelaskan oleh variabel dependen yaitu variabel diskusi suami dan diskusi istri sedangkan sisanya sebesar 85,3\% kunjungan ANC dipengaruhi oleh variabel-variabel lain dari luar model penelitian seperti, pendapatan, fasilitas kesehatan, dukungan keluarga, dan lainnya.

\subsubsection{Tabel Klasifikasi}

Tabel 15. Tabel Klasifikasi

\begin{tabular}{ccccc}
\hline \multirow{2}{*}{ Observed } & \multicolumn{3}{c}{ Predicted } \\
\cline { 2 - 5 } & \multicolumn{2}{c}{ KunjunganANC } & Percentage Correct \\
\cline { 2 - 5 } & $\mathbf{0}$ & $\mathbf{1}$ & 75,5 \\
\hline Step 1KunjunganANC & 0 & 40 & 13 & 52,5 \\
\cline { 2 - 5 } & 1 & 28 & 31 & 63,4 \\
\cline { 2 - 4 } & Overall Percentage & & & \\
\hline
\end{tabular}

Berdasarkan tabel 15 hasil dari tabel tersebut menyatakan bahwa dengan menggunakan model regresi tersebut, terdapat pasangan suami-istri yang melakukan kunjungan ANC sebanyak 13 (75,5\%) diprediksi akan melakukan diskusi antara suami-isttri dari total sampel. Kekuatan prediksi dari model regresi untuk memprediksi kemungkinan pasangan suami-istri melakukan diskusi bersama untuk kepatuhan kunjungan ANC sebanyak 31 (52,5\%) dari total sampel. 


\subsubsection{Model Regresi Logistik}

Tabel 16. Model Regresi Logistik

\begin{tabular}{ccccccccc}
\hline & \multirow{2}{*}{ B } & \multirow{2}{*}{ S.E. } & Wald & Df & Sig. & \multirow{2}{*}{ Exp(B) } & \multicolumn{2}{c}{ 95\% C.I.for EXP(B) } \\
Lower & Upper \\
\hline Step 1a Diskusi Suami(1) & $-2,078$ & 0,676 & 9,455 & 1 & 0,002 & 0,125 & 0,033 & 0,471 \\
Diskusi Istri(1) & $-1,176$ & 0,670 & 3,082 & 1 & 0,079 & 0,309 & 0,083 & 1,147 \\
Constant & 1,854 & 0,679 & 7,457 & 1 & 0,006 & 6,386 & & \\
\hline
\end{tabular}

Bentuk persamaan regresi logistik sebagai berikut:

$\operatorname{Ln} \frac{T P}{1-T P}=1,854-2,078$ Diskusi suami $-1,176$ Diskusi istri $+e$

Persamaan tersebut dapat dijelaskan sebagai berikut: (1) Nilai dari koefisien variabel konstanta pada persamaan regresi logistik adalah sebesar 1,854 hal ini menyatakan bahwa tanpa ada variabel diskusi suami, diskusi istri maka kemungkinan pasangan suami istri akan cenderung melakukan kunjungan ANC. (2) Variabel diskusi suami memiliki nilai koefisien 2,078 bertanda negatif (-) menunjukkan bahwa semakin tinggi tingkat diskusi suami memiliki kecenderungan untuk tidak melakukan kunjungan ANC. Nilai odds ratio yang diprediksi oleh model pada variabel diskusi suami dengan nilai Exp (B) 0,125 . Diperoleh nilai $\mathrm{e}^{(0,125)}=$ $2,718^{(0,125)}=1,1331$ menunjukkan bahwa semakin tinggi faktor diskusi suami akan meningkatkan kecenderungan peran diskusi suami untuk melakukan kunjungan ANC sebesar 1,1331 kali lebih tinggi dibandingkan dengan tidak melakukan diskusi suami. (3) Variabel diskusi istri memiliki nilai koefisien $-1,176$ bertanda negatif $(-)$ menunjukkan bahwa semakin tinggi tingkat diskusi istri memiliki kecenderungan untuk tidak melakukan kunjungan ANC. Nilai odds ratio yang diprediksi oleh model pada variabel diskusi istri dengan nilai Exp (B) 0,309 . Diperoleh nilai $\mathrm{e}^{(0,309)}=2,718^{(0,309)}=1,362$ menunjukkan bahwa semakin tinggi faktor diskusi istri akan meningkatkan kecenderungan peran diskusi istri untuk melakukan kunjungan ANC sebesar 1,362 kali lebih tinggi dibandingkan dengan tidak melakukan diskusi istri. (4) Nilai signifikansi pada variabel diskusi suami sebesar $0,002<\alpha=0,05$ adalah variabel bebas diskusi suami memiliki pengaruh terhadap variabel terikat kunjungan ANC. Nilai signifikansi pada variabel diskusi istri sebesar 0,079 $>\alpha=0,05$ adalah variabel bebas diskusi istri tidak memiliki pengaruh terhadap variabel terikat kunjungan ANC.

\subsection{Pembahasan}

\subsection{Diskusi Suami Terhadap Kunjungan ANC}

Berdasarkan hasil penelitian ini pada diskusi suami terhadap kunjungan ANC di RSUD Dr. H. Slamet Martodirdjo diperoleh bahwa diskusi suami sebagian besar kategori rendah sebesar 40 atau (35,7\%) dengan kunjungan ANC yang sesuai. Hasil analisis Chi-Square diperoleh nilai $\mathrm{p}$ value $=0,002$ lebih kecil dari $\alpha=0,05$ yang berarti bahwa ada pengaruh antara diskusi suami terhadap kunjungan ANC di RSUD Dr. H. Slamet Martodirdjo.

Hasil penelitian ini sesuai dengan Subratha dan Ni Wayan (2014) yang menunjukkan hasil penelitian bahwa dari 50 responden yang diteliti sebesar 26 responden memiliki 
dukungan suami yang kurang dengan kunjungan ANC tidak sesuai standar. Data tersebut menunjukkan suami yang kurang mendukung pasangannya akan menghasilkan kunjungan ANC tidak sesuai dengan standar. Hal tersebut dikarenakan diskusi suami terhadap ibu hamil atau istri tidak terlepas dari beberapa faktor seperti tingkat pendidikan, pendapatan, status sosial ekonomi, status perkawinan, budaya (Bobak, 2010).

Berdasarkan karakteristik kategori pendidikan suami yang diperoleh dari penelitian pada 112 responden, diperoleh mayoritas suami berpendidikan tamat SLTA/sederajat sebesar 57 atau 51\% suami. Wawasan dan pengetahuan yang rendah dapat menyebabkan rendahnya akses terhadap informasi kesehatan istri sehingga suami akan menjadi sulit dalam mengambil keputusan yang tepat.

\subsection{Diskusi Istri Terhadap Kunjungan ANC}

Berdasarkan hasil penelitian ini pada diskusi istri terhadap kunjungan ANC di RSUD Dr. H. Slamet Martodirdjo diperoleh bahwa diskusi istri berkategori rendah sebesar 25 atau $(22,3 \%)$ dengan kunjungan ANC yang sesuai. Hasil analisis Chi-Square diperoleh nilai p value = 0,480 lebih besar dari $\alpha=0,05$ menunjukkan bahwa tidak ada pengaruh antara diskusi istri terhadap kunjungan ANC di RSUD Dr. H. Slamet Martodirdjo.

Menurut peneliti ibu hamil dengan kunjungan ANC yang tidak sesuai merupakan masalah yang besar bagi kehamilan ibu karena pemeriksaan ANC bermanfaat untuk mendeteksi secara dini, mencegah komplikasi dalam kehamilan dan memantau perkembangan janin selama kehamilan. Ibu hamil yang tidak sesuai melakukan pemeriksaan ANC perlu mendapatkan perhatian serius dari segala pihak baik dari ibu hamil itu sendiri, suami, keluarga ataupun petugas kesehatan setempat agar tidak berdampak buruk pada ibu dan janin baik pada saat kehamilan maupun persalinan (Dinaria, 2016).

Kunjungan ANC yang tidak sesuai pada ibu hamil bisa disebabkan oleh dirinya sendiri atau faktor internal seperti, pendidikan, usia, pekerjaan. Hal tersebut berkaitan pada penelitian dengan karakteristik pendidikan istri yang menyatakan bahwa kategori pendidikan masih tergolong rendah dilihat dari segi tamat SD, tamat SLTP/Sederajat dan tamat SLTA/Sederajat sebanyak 56 atau 61\% dibandingkan dengan Akademi/Perguruan Tinggi sebanyak 44 atau $39 \%$.

Mukaromah dan Saenum (2014) menyatakan pendidikan merupakan ibu hamil pengetahuan tentang ANC. Pendidikan yang tinggi serta pengetahuan yang baik membuat ibu hamil mudah menerima informasi serta melaksanakan kunjungan ANC dengan teratur, memeriksakan kehamilannya menyesuaikan standar pemeriksaan kehamilan (ANC) demi melindungi keadaan kesehatan dirinya serta anak dalam kandungannya. Perihal ini sesuai dengan penelitian Sari, Fitriana dan Anggraini (2015) yang menyatakan bahwa semakin tinggi tingkatan pendidikan ibu hamil maka akan sesuai dengan jadwal pelaksanaan pemeriksaan kehamilan ke fasilitas kesehatan.

Novianna (2018) menyatakan bahwa tingkat pendidikan ibu hamil yang mempunyai makna statisk yaitu $\alpha=0,05$ lebih kecil dibandingkan $p$ value $=0,007$, sehingga dapat disimpulkan terdapat ada hubungan antara tingkat pendidikan ibu hamil terhadap kepatuhan melakukan ANC di RSI Pekajangan. Ibu hamil dengan pendidikan rendah, berdasarkan odd 
ratio yang diperoleh sebesar 3,6 kali berisiko untuk tidak patuh daripada ibu dengan pendidikan tinggi.

Selain itu, Ningsih (2017) dan Wulandari (2016) menyatakan bahwa semakin tinggi pendidikan ibu, maka semakin mudah ibu hamil mendapatkan informasi tentang ANC. Begitu pula sebaliknya, seseorang dengan tingkat pendidikan yang rendah cenderung lebih tertutup dan lebih sulit dalam hal pengambilan keputusan, akibatnya bila ada informasi baru, proses penerimaannya lebih lambat (Syamsiah, N \& Putrikasari, A. 2018).

\section{Simpulan}

Berdasarkan hasil penelitian peran diskusi suami istri terhadap kepatuhan kunjungan antenatal care (ANC) (Analisis Data Rsud Dr. H. Slamet Martodirdjo Pamekasan), maka dapat disimpulkan bahwa sebagai berikut: (1) Dari hasil distribusi frekuensi kunjungan ANC diperoleh bahwa kunjungan ANC dengan kategori sesuai sebesar $47 \%$ atau 53, sedangkan tidak sesuai 53\% atau 59 keseluruhan responden. (2) Dari hasil analisis antara diskusi suami dan kunjungan ANC diperoleh Nilai odds ratio terdapat sebesar 1,1331. Artinya diskusi suami memiliki peran sebanyak 1.1331 kali dalam mendorong pelaksanaan kepatuhan kunjungan ANC RSUD Dr. H. Slamet Martodirdjo Pamekasan. (3) Dari hasil analisis antara diskusi istri dan kunjungan ANC diperoleh Nilai odds ratio terdapat sebesar 1,362. Artinya diskusi istri memiliki peran sebanyak 1,1362 kali dalam mendorong pelaksanaan kepatuhan kunjungan ANC RSUD Dr. H. Slamet Martodirdjo Pamekasan.

\section{Daftar Rujukan}

Bobak, I. M., Lowdermilk, D. L., Jensen, M. D., \& Perry, S. E. (2018). Buku ajar keperawatan maternitas. Jakarta: Egc.

Dinas Kesehatan Provinsi Jawa Timur. (2018). Profil Kesehatan Provinsi Jawa Timur 2018. Surabaya: Dinas Kesehatan Provinsi Jawa Timur.

Dinas Kesehatan Provinsi Bali. (2017). Profil Kesehatan Provinsi Bali Tahun 2016.Bali: Dinas Kesehatan Porvinsi Bali

Dinaria. (2016). Dukungan Suami Dan Status Pekerjaan Ibu Dengan Kepatuhan Ibu Hamil Dalam Pemeriksaan ANC, Surabaya, Akademi Kebidanan Griya Husada.

Kementerian Kesehatan RI. (2018). Profil kesehatan Indonesia 2017. Jakarta: Kementerian Kesehatan RI.

Mukaromah, H., \& Saenum. (2014). Analisis Faktor Ibu Hamil Terhadap Kunjungan Antenatal Care di Puskesmas Siwalankerto Kecamatan Wonocolo Kota Surabaya. Jurnal Promosi Dan Pendidikan Kesehatan Indonesia, 2(1), 39-48.

Pakki, I. B. (2018). Hubungan Pengetahuan, Sikap dan Dukungan Suami terhadap Kepatuhan Pemeriksaan Antenatal Care (Anc) pada Ibu Hamil di Kecamatan Loa Kulu Kabupaten Kutai Karta Negara. CHMK Health Journal, 2(2), 50-50.

Sari \& Eny. (2015). Hubungan Dukungan Suami Dengan Ketepatan ANC Di Desa Bagi Kabupaten Madiun. Prosiding: Seminar Nasional dan Presentasi Hasil-Hasil Penelitian Pengabdian Masyarakat. Hal. 263271.Akademi Kebidanan Muhammadiyah Madiun

Sari, G. N., Fitriana, S., \& Anggraini, D. H. (2015). Faktor Pendidikan, Pengetahuan, Paritas, Dukungan Keluarga dan Penghasilan Keluarga yang Berhubungan dengan Pemanfaatan Pelayanan Antenatal. Jurnal Ilmu Dan Teknologi Kesehatan, 2(2), 77-82.

Uktutias, S. A. M., Pratiwi, N. L., \& Purnomo, W. (2018). Pengaruh Kesadaran Situasi Ibu Hamil Dengan Frekuensi Kunjungan Antenatal di Wilayah Kerja Puskesmas Waru Kabupaten Pamekasan Tahun 2016. Buletin Penelitian Sistem Kesehatan, 21(1), 15-21.

Sugiyono. (2011). Metode Penelitian Kuantitatif, Kualitatif dan R\&D. Bandung: Alfabeta.

Sunaryo, (2004). Psikologi Untuk Keperawatan. Jakarta: EGC. 
Sport Science and Health, 3(10), 2021, 814-825

Subratha, H. F. A., \& Kartiningsih, N. W. M. (2018). Hubungan Dukungan Suami Dengan Kunjungan Antenatal Care (Anc) Pada Ibu Hamil Di Kabupaten Tabanan. Jurnal Medika Usada, 1(1).

Syamsiah, N. \& Putrikasari, A. (2018). Faktor-Faktor Yang Berhubungan Dengan Kunjungan Antenatal Care Pada Ibu Hamil Dipuskesmas Kecamatan Kembang Jakarta Barat. Bandung

Notoatmodjo, S. (2010). Metodologi Penelitian Kesehatan. Jakarta: Rineka Cipta.

Notoatmodjo. (2018). Metodologi Penelitian Kesehatan.

Ningsih, E. S. (2018). Hubungan Tingkat Pendidikan Ibu Hamil Trimester III dengan Keteraturan Kunjungan ANC. Jurnal Midpro, 9(2), 5.

Wulandari, E,.S .(2016). Faktor-Faktor Yang Berhubungan Dengan Pemeriksaan Antenatal Care Kunjungan Pertama K1 Pada Ibu Hamil. Jakarta. Universitas Islam Negeri Syarif Hidayatullah Jakarta

World Health Organization (WHO). (2018). Global Health Observatory (GHO) data Maternal Mortality 